\title{
Assessment Nurses' Knowledge about Hemophilia for Children attending Heredity Blood Disease Center in Al-Nasiriya City
}

\author{
Oday Faris Washeel, MScn* Eqbal Ghanim Ma'ala, PhD** \\ * Assistant Instructor, Pediatrics Nursing Department of Nursing College, Al-Muthana University \\ ** Professor, Pediatrics Nursing Department of Nursing College, University of Baghdad
}

\begin{abstract}
Background: Hemophilia is a coagulation disorder arising from a genetic defect of the $X$ chromosome; the defect can either be inherited or result from spontaneous gene mutation. In each type of hemophilia (A, B, and $C)$, a critical coagulation protein is missing, causing individuals to bleed for long periods of time before clotting occurs.
\end{abstract}

Objectives: 1-Assess the pediatric nurses' knowledge toward hemophilia in children.

2-Find out the factors that affecting the knowledge of the sample.

Subjects and methods A descriptive study was conducted on pediatric nurses who were dealing with the children who have hemophilia, carried out in Nasiriya city / Heredity Blood Disease Center starting from May /2016 to April/2017.

Results: Based on the results the researcher found that $41.2 \%$ of the study sample between (30-39) years of age, $64.7 \%$ females, $47.1 \%$ had diploma in nursing, $41.2 \%$ had more than 10 years of services, $52.9 \%$ their monthly income were Sufficient somewhat, $64.7 \%$ live in urban area, $82.4 \%$ of them not has cars, $41.2 \%$ of them possession houses and $70.6 \%$ were unmarried. the nurses respondent to hemophilia knowledge (41 items nurses has low level of assessment when responses to knowledge question, has moderate level of knowledge when responses to knowledge question (47 items has moderate level of assessment according to the mean of score, and 12 items has high level of assessment from total items 100). According to the nurses knowledge total score, this shows (52.9\%) of nurses had poor level of knowledge. There is statistical significant association between nurses' educational level and their knowledge concerning hemophilic child at pre-test of educational program follow up ( $p$ value < 0.05$)$ when analyzed by ANOVA. there is No statistical significant association between nurses' (other demographic data) and their knowledge concerning hemophilic child at pre test

Conclusion: The study indicated that the nurses have high rates of acceptable level in knowledge related to definition, type of hemophilia, the hereditary role in the transmission of hemophilia and treatment process of the disease the finding showed that the nurses have a unacceptable level in the knowledge, regarding the type of bleeding in hemophilia is internal and external, place of internal bleeding, the incidence of hemophilia in the families don't have history of the disease, types, other names of hemophilia B, the samples information about genetic roles for males and females to be incidence with hemophilia and the clotting process with the role of factors VIII , IX And these results have a bad effect on quality of care which provided for the pediatric patient. The result of the study found that most of the sample have uncertain information regarding the effect of hemophilia through bleeding on the life style of the carriers and the main complication to replacement therapy is the antibodies respectively. There is statistical significant association between nurses' educational level and their knowledge concerning hemophilic child.

Recommendations: Special training courses should be designed and constructed for nurses in relation to hemophilia. Nurse in hematological units must take their opportunity for continuing education. Increasing the number of professional nurses assigned to work in the pediatric and blood disease wards. Motivate the nurses to improve their knowledge and practices which help improve their performance with the patients. Providing scientific booklet, publication and journal about hemophilia in nursing educational program.

Keywords: Hemophilia, Knowledge, Children

\section{Introduction}

Hemophilia usually occurs in males (with rare exceptions) and about 1 in 5,000 males are born with hemophilia each year(Bolton and Pasi.2003). Hemophilia B, also known as factor IX deficiency or Christmas disease, is an X-linked bleeding disorder caused by defects in the vitamin $\mathrm{K}$ dependent enzyme factor IX of the clotting cascade( Franchini.,2006). Factor IX is also known as the Christmas factor, hence the association of hemophilia B with the term Christmas disease (Giangrande.,2005). Activated Factor IX (factor IXa) is the enzyme responsible for the activation of factor $\mathrm{X}$ to $\mathrm{Xa}$ in a reaction referred to as the "tenase" complex. A cofactor in this reaction is factor VIII, deficiencies in which result in hemophilia A (Roosendaal \& Lafeber., 2007 ). Multiple mutations have been identified leading to hemophilia (B). A complete compilation of all of the 
mutations can be found at the hemophilia B database. Hemophilia B results in a bleeding disorder that is clinically indistinguishable from the more common hemophilia A (Graw .J, et al 2005). Hemophilia B occurs in approximately 1 in 30,000 male births (Oldenburg., El-Maarri., 2006).The other type of hemophilia is Hemophilia C, which is a mild form of hemophilia affecting both sexes. However, it predominantly occurs in Jews. It is the fourth most common coagulation disorder after von Willebrand's disease and hemophilia A and B. In the USA it is thought to affect 1 in 100,000 of the adult population, making it $10 \%$ as common as hemophilia (Johnson., et al 2007). Person with Hemophilia $\mathrm{C}$ has low levels of or is missing completely factor 11 (Also called F XI or factor XI deficiency) Hemophilia C is 10 times more rare than type A or B. Factor XI deficiency in Hemophilia $\mathrm{C}$ is different from the other types of Hemophilia, because it can show up in both males and females. In hemophilia while all acute bleeding episodes are considered serious and emergent, there are five major sites of serious bleeding in hemophilia that threaten life, limb, or function. They are intracranial or spinal cord bleeds, throat bleeds, intra-abdominal bleeds, limb compartment syndromes (e.g. thigh, calf, forearm, upper arm) and ocular bleeds. All of these areas are characterized by bleeding into an enclosed space, compression of vital tissue, and potential loss of life, limb, or function. Since bleeding episodes also cause anxiety and fear in patients and families, the nursing interventions of communication, reassurance, education, and support will help them through these crises (Leticia, et al. 2012).

\section{Objectives of the study:}

1-Assess the pediatric nurses' knowledge toward hemophilia in children.

2-Find out the factors that affecting the knowledge of the sample.

\section{Subjects And Methods}

Non -probability (purposive) sample of (17) nurses who deal with children from the pediatric hospitals and wards in Kirkuk city which they are dealing with hemophilic patients. For data collection The instrument was designed and constructed by the investigators to measure the variable underlying the present study, after review of literature. Data were obtained by the investigator who interviewed the nurses and filling the structural questionnaire format for the demographic items, knowledge items. The questionnaire consists of two parts: Part I This part of the questionnaire included demographic data related to the respondents characteristics such as age ,gender, level of education, years of experience in general wards and experience in oncology wards and whether they have continuing education or not. Part II This part of the consists of (30) items includes the structural items concerning knowledge of the sample toward hemophilia. This includes the general information, definition, sign and symptoms and the treatment, which is constructed from review of related literatures and previous studies. Interviewing techniques are used. In order to measure the previous items accurately and statistically, likert scale are used and scores to find out the knowledge of the pediatric nurse were used to identify the level of knowledge which it's determined by mean of score as a following: level of assessment $(1-1.33)=$ low Knowledge $=\mathrm{L}$, $(1.34-1.67)=$ moderate Knowledge $=\mathrm{M},(1.68-2.00)=$ high Knowledge $=\mathrm{H}$. The data of present study were analyzed through the application of two statistical approaches, which may assist for the determination of the study results. These approaches include Frequencies, Percentage, Mean of scores and one way ANOVA the significance different between the variables (L.K) (Polit., \& Hungler.,2009).

Table ( 1 ) Distribution of the Study Sample by their General Information

\begin{tabular}{|l|l|l|l|}
\hline Variables & No. & \% \\
\hline \multirow{4}{*}{ Ages (years) } & $20-29$ Year & 6 & 35.3 \\
\cline { 2 - 4 } & $30-39$ Year & 7 & 41.2 \\
\cline { 2 - 4 } & $40-49$ Year & 4 & 23.5 \\
\cline { 2 - 4 } & $50-59$ Year & - & - \\
\cline { 2 - 4 } & Total & 17 & 100.0 \\
\hline \multirow{5}{*}{ level of education } & Male & 6 & 35.3 \\
\cline { 2 - 4 } & Female & 11 & 64.7 \\
\cline { 2 - 4 } & Total & 17 & 100.0 \\
\hline \multirow{5}{*}{ Years of service } & Nursing Course & - & - \\
\cline { 2 - 4 } & Secondary Nursing School & 6 & 35.3 \\
\cline { 2 - 4 } & Nursing Institute & 8 & 47.1 \\
\cline { 2 - 4 } & Bachelor of Nursing & 3 & 17.6 \\
\cline { 2 - 4 } & Total & 17 & 100.0 \\
\hline \multirow{3}{*}{ Monthly income } & Lees than 2Years & 4 & 23.5 \\
\cline { 2 - 4 } & $2-5$ Years & 4 & 23.5 \\
\cline { 2 - 4 } & $5-10$ Years & 2 & 11.8 \\
\cline { 2 - 4 } & More than 10 years & 7 & 41.2 \\
\cline { 2 - 4 } & Total & 17 & 100.0 \\
\hline & Sufficient & 2 & 52.9 \\
\cline { 2 - 4 } & Sufficient somewhat & 9 & 35.3 \\
\cline { 2 - 3 } & Insufficient & 6 & \\
\hline
\end{tabular}


Assessment Nurses' Knowledge about Hemophilia for Children attending Heredity Blood Disease

\begin{tabular}{|l|l|l|l|}
\hline & Total & 17 & 100.0 \\
\hline \multirow{4}{*}{ Residential area } & Rural & 6 & 35.3 \\
& Urban & 11 & 64.7 \\
\cline { 2 - 4 } & Total & 17 & 100.0 \\
\hline \multirow{5}{*}{ Transport } & Owns & 3 & 17.6 \\
\cline { 2 - 4 } & Non owns & 14 & 82.4 \\
\cline { 2 - 4 } & Total & 17 & 100.0 \\
\hline \multirow{5}{*}{ Marital status } & possession & 7 & 41.2 \\
\cline { 2 - 4 } & common property & 6 & 35.3 \\
\cline { 2 - 4 } & leasehold & 3 & 17.6 \\
\cline { 2 - 4 } & other & 1 & 17.9 \\
\cline { 2 - 4 } & Total & 17 & 100.0 \\
\hline & Married & 2 & 11.8 \\
\cline { 2 - 3 } & unmarried & 3 & 70.6 \\
\cline { 2 - 3 } & Single & 17 & 17.6 \\
\cline { 2 - 3 } & Total & 100.0 \\
\hline
\end{tabular}

No.= number, $\%=$ percentage

This table shows that $41.2 \%$ of the study sample between (30-39) years of age, $64.7 \%$ females, $47.1 \%$ had diploma in nursing, $41.2 \%$ had more than 10 years of services, $52.9 \%$ their monthly income were Sufficient somewhat, $64.7 \%$ live in urban area, $82.4 \%$ of them not has cars, $41.2 \%$ of them possession houses and $70.6 \%$ were unmarried.

Table ( 2 ) Distribution of Nurses responses to hemophilia knowledge

\begin{tabular}{|c|c|c|c|c|c|c|c|}
\hline \multirow[t]{2}{*}{ No. } & \multirow[t]{2}{*}{ Questions } & \multicolumn{2}{|c|}{ True answer } & \multicolumn{2}{|c|}{ False answer } & \multirow[t]{2}{*}{ M. S } & \multirow[t]{2}{*}{ Ass. } \\
\hline & & f & $\%$ & f & $\%$ & & \\
\hline 1 & $\begin{array}{l}\text { Heredity bleeding is one the following (Thalassemia, } \\
\text { Hemophilia , Sickle cell anemia, Leukemia) }\end{array}$ & 7 & 41.2 & 10 & 58.8 & 1.41 & M \\
\hline 2 & $\begin{array}{l}\text { The most common type of hemophilia in (Male, } \\
\text { Females, both of them) }\end{array}$ & 8 & 47.1 & 9 & 52.9 & 1.47 & M \\
\hline \multicolumn{8}{|c|}{ 3. Bleeding occurs in patients with hemophilia for the first time } \\
\hline $3-1$ & Automatically (spontaneous) $\quad \checkmark$ & 5 & 29.4 & 12 & 70.6 & 1.29 & $\mathbf{L}$ \\
\hline $3-2$ & Bruising & 6 & 35.3 & 11 & 64.7 & 1.35 & $\mathbf{M}$ \\
\hline $3-3$ & Circumcision & 5 & 29.4 & 12 & 70.6 & 1.29 & $\mathbf{L}$ \\
\hline $3-4$ & Bleeding wounds (Nose, Mouth) & - & - & 17 & 100 & 1 & $\mathbf{L}$ \\
\hline $3-5$ & $\begin{array}{l}\text { During childbirth and while cutting the umbilical cord } \\
\checkmark\end{array}$ & 11 & 64.7 & 6 & 35.3 & 1.35 & M \\
\hline \multicolumn{8}{|c|}{ 4. Symptoms of joint hemophilic Child bleeding } \\
\hline 4-1 & Swelling and Pain & 4 & 23.5 & 13 & 76.5 & 1.235 & $\mathbf{L}$ \\
\hline $4-2$ & Numbness & 5 & 29.4 & 12 & 70.6 & 1.29 & $\mathbf{L}$ \\
\hline $4-3$ & Range of motion of the joint is limited & 12 & 70.6 & 5 & 29.4 & 1.71 & $\mathbf{H}$ \\
\hline \multicolumn{8}{|c|}{ 5. Hemophilia patient who is suffering from (Hematuria) encourage him to } \\
\hline $5-1$ & Bed rest for 24 hours $\quad \checkmark$ & 10 & 58.8 & 7 & 41.2 & 1.59 & $\mathbf{M}$ \\
\hline $5-2$ & Increase fluid intake $\quad \checkmark$ & 4 & 23.5 & 13 & 76.5 & 1.235 & $\mathbf{L}$ \\
\hline $5-3$ & $\begin{array}{l}\text { Seek advice from the nearest treatment center or blood } \\
\text { diseases center }\end{array}$ & 7 & 41.2 & 10 & 58.8 & 1.41 & $\mathbf{M}$ \\
\hline \multicolumn{8}{|c|}{ 6. Treatment is given by intravenous infusion sites (IV) for hemophilic child are } \\
\hline $6-1$ & $\begin{array}{ll}\text { Hands back } & \checkmark \\
\end{array}$ & 12 & 70.6 & 5 & 29.4 & 1.71 & $\mathbf{H}$ \\
\hline $6-2$ & $\begin{array}{l}\text { Front elbow joint (the soles of the elbow joint) (caution in } \\
\text { infants) }\end{array}$ & 5 & 29.4 & 12 & 70.6 & 1.29 & $\mathbf{L}$ \\
\hline $6-3$ & Back foot, especially (infants \& children) $\quad \checkmark$ & 11 & 64.7 & 6 & 35.3 & 1.65 & $\mathbf{M}$ \\
\hline $6-4$ & Scalp Veins (infants only) & 12 & 70.6 & 5 & 29.4 & 1.71 & $\mathbf{H}$ \\
\hline \multicolumn{8}{|c|}{ 7. The most common types of viral hepatitis become infected hemophilic child are } \\
\hline $7-1$ & Hepatitis A (HAV Transmission by Fecal-oral) @ & 12 & 70.6 & 5 & 29.4 & 1.29 & $\mathbf{L}$ \\
\hline $7-2$ & Hepatitis B (HBV Transmission by Blood) $\checkmark \checkmark$ & 6 & 35.3 & 11 & 64.7 & 1.35 & M \\
\hline $7-3$ & Hepatitis C (HCV Transmission by Blood) & 6 & 35.3 & 11 & 64.7 & 1.35 & $\mathbf{M}$ \\
\hline $7-4$ & Hepatitis D (HDV Transmission by Blood) & 9 & 52.9 & 8 & 47.1 & 1.47 & $\mathbf{M}$ \\
\hline $7-5$ & Hepatitis E (HEV Transmission by Fecal-oral) ${ }^{\circledR}$ & 11 & 64.7 & 6 & 35.3 & 1.35 & $\mathbf{M}$ \\
\hline $7-6$ & Hepatitis G (HGV Transmission Unknown) ${ }^{\circledR}$ & 8 & 47.1 & 9 & 52.9 & 1.53 & M \\
\hline 8 & $\begin{array}{l}\text { When one of the clotting factors is missing, or low, } \\
\text { hemorrhage continues ( long or short period) }\end{array}$ & 17 & 100 & - & - & 2 & $\mathbf{H}$ \\
\hline 9 & $\begin{array}{l}\text { Hemophilia it chromosomes defect of parents especially } \\
\text { chromosome }(X, Y)\end{array}$ & 13 & 76.5 & 4 & 23.5 & 1.76 & $\mathbf{H}$ \\
\hline 10 & $\begin{array}{l}\text { When a mother gene hemophilia, the chances of passing } \\
\text { the gene to child's }(25 \%, 50 \%, 100 \%)\end{array}$ & 7 & 41.2 & 10 & 58.8 & 1.41 & M \\
\hline 11 & $\begin{array}{l}\text { The man with hemophilia passes the disease to all ( son, } \\
\text { Daughters) }\end{array}$ & 8 & 47.1 & 9 & 52.9 & 1.47 & M \\
\hline \multicolumn{8}{|c|}{ 12. Three bleeding joints more occurs are } \\
\hline $12-1$ & Shoulder & 11 & 64.7 & 6 & 35.3 & 1.35 & M \\
\hline
\end{tabular}


Assessment Nurses' Knowledge about Hemophilia for Children attending Heredity Blood Disease

\begin{tabular}{|c|c|c|c|c|c|c|c|}
\hline $12-2$ & Elbow & 8 & 47.1 & 9 & 52.9 & 1.47 & $\mathbf{M}$ \\
\hline $12-3$ & Ankle & 8 & 47.1 & 9 & 52.9 & 1.47 & $\mathbf{M}$ \\
\hline $12-4$ & Hip & 9 & 52.9 & 8 & 47.1 & 1.47 & $\mathbf{M}$ \\
\hline $12-5$ & Knee & 8 & 47.1 & 9 & 52.9 & 1.47 & $\mathbf{M}$ \\
\hline \multicolumn{8}{|c|}{ 13. Most common of muscular bleeding area in } \\
\hline $13-1$ & leg Calf muscle $\quad \checkmark$ & 5 & 29.4 & 12 & 70.6 & 1.29 & $\mathbf{L}$ \\
\hline $13-2$ & Thigh & 17 & 100 & - & - & 1 & $\mathbf{L}$ \\
\hline $13-3$ & Arm & 17 & 100 & - & - & 1 & $\mathbf{L}$ \\
\hline $13-4$ & Abdomen & 17 & 100 & - & - & 1 & $\mathbf{L}$ \\
\hline $13-5$ & lumbar muscle & 5 & 29.4 & 12 & 70.6 & 1.29 & $\mathbf{L}$ \\
\hline \multicolumn{8}{|c|}{ 14. Sports games that are not recommended for hemophilic child } \\
\hline $14-1$ & Football, Table tennis $\quad \checkmark$ & 7 & 41.1 & 10 & 58.9 & 1.41 & $\mathbf{M}$ \\
\hline $14-2$ & Wrestling, Karate, Judo & 4 & 23.5 & 13 & 76.5 & 1.235 & $\mathbf{L}$ \\
\hline $14-3$ & Scooters & 14 & 82.4 & 3 & 17.6 & 1.17 & $\mathbf{L}$ \\
\hline $14-4$ & Billiard, Badminton & 11 & 64.7 & 6 & 35.3 & 1.35 & $\mathbf{M}$ \\
\hline \multicolumn{8}{|c|}{ 15. Recommended sports for people with hemophilia include } \\
\hline $15-1$ & Swimming $\quad \checkmark$ & 8 & 47.1 & 9 & 52.9 & 1.47 & $\mathbf{M}$ \\
\hline $15-2$ & Table Tennis & 12 & 70.59 & 5 & 29.41 & 1.7 & $\mathbf{H}$ \\
\hline $15-3$ & Fishing & 6 & 35.29 & 11 & 64.71 & 1.35 & $\mathbf{M}$ \\
\hline $15-4$ & Golf, bowling, billiards & 8 & 47.1 & 9 & 52.9 & 1.47 & $\mathbf{M}$ \\
\hline \multicolumn{8}{|c|}{ 16. Symptoms of external bleeding of Hemophilia } \\
\hline $16-1$ & Blood visible appearance $\quad \checkmark$ & 17 & 100 & - & - & 2 & $\mathbf{H}$ \\
\hline $16-2$ & Feeling tired & 10 & 52.8 & 7 & 41.2 & 1.41 & $\mathbf{M}$ \\
\hline $16-3$ & Bruises and abrasions & 6 & 35.29 & 11 & 64.71 & 1.35 & $\mathbf{M}$ \\
\hline $16-4$ & Dizziness & 17 & 100 & - & - & 1 & $\mathbf{L}$ \\
\hline \multicolumn{8}{|c|}{ 17. Complications of Hemophilia } \\
\hline $17-1$ & Joint deformity & 8 & 47.1 & 9 & 52.9 & 1.47 & $\mathbf{M}$ \\
\hline $17-2$ & Synovitis + arthropathy chronic Hemorrhagic $\checkmark$ & 6 & 35.29 & 11 & 64.71 & 1.35 & $\mathbf{M}$ \\
\hline $17-3$ & AIDS and hepatitis $\quad \checkmark$ & 5 & 29.4 & 12 & 70.6 & 1.29 & $\mathbf{L}$ \\
\hline \multicolumn{8}{|c|}{ 18. The nature of food for hemophilic child are } \\
\hline $18-1$ & Easy chewing and digestion $\quad \checkmark$ & 10 & 52.8 & 7 & 41.2 & 1.59 & $\mathbf{M}$ \\
\hline $18-2$ & Do not lead to obesity & 12 & 70.6 & 5 & 29.4 & 1.7 & $\mathbf{H}$ \\
\hline $18-3$ & Food rich in iron and protein $\quad \checkmark$ & 10 & 52.8 & 7 & 41.2 & 1.59 & $\mathbf{M}$ \\
\hline \multicolumn{8}{|c|}{ 19. Early care for hemophilia disease contribute to } \\
\hline $19-1$ & Reduce complications in the future $\checkmark$ & 14 & 82.35 & 3 & 17.65 & 1.82 & $\mathbf{H}$ \\
\hline $19-2$ & Reduce the amount of blood lost $\checkmark \checkmark$ & 8 & 47.1 & 9 & 52.9 & 1.47 & $\mathbf{M}$ \\
\hline $19-3$ & $\begin{array}{l}\text { Reduce the absences of the child from school and work } \\
\text { ( }\end{array}$ & 4 & 23.5 & 11 & 76.5 & 1.18 & $\mathbf{L}$ \\
\hline $19-4$ & live fully health and wellbeing $\quad \checkmark$ & 3 & 17.65 & 14 & 82.35 & 1.12 & $\mathbf{L}$ \\
\hline \multicolumn{8}{|c|}{ 20. Recommend the patient on a regular basis because assisted therapy } \\
\hline $20-1$ & Play sports on a regular basis $\quad \checkmark$ & 2 & 11.8 & 15 & 88.2 & 1.12 & $\mathbf{L}$ \\
\hline $20-2$ & live a close to his peers & 3 & 17.65 & 14 & 82.35 & 1.12 & $\mathbf{L}$ \\
\hline $20-3$ & Grow and develop and play normally $\checkmark$ & 6 & 35.29 & 11 & 64.71 & 1.35 & $\mathbf{M}$ \\
\hline \multicolumn{8}{|c|}{ 21.Hemophilia patients are advised to oral and dental care } \\
\hline $21-1$ & Use a very soft brush $\quad \checkmark$ & 11 & 64.71 & 6 & 35.29 & 1.65 & $\mathbf{M}$ \\
\hline $21-2$ & Brushing teeth slowly & 4 & 23.53 & 13 & 76.47 & 1.23 & $\mathbf{L}$ \\
\hline $21-3$ & $\begin{array}{l}\text { Check daily for the mouth and teeth of the child by the } \\
\text { parents }\end{array}$ & 6 & 35.29 & 11 & 64.71 & 1.35 & $\bar{M}$ \\
\hline $21-4$ & $\begin{array}{l}\text { Examination of the mouth and teeth by a dentist on a regular } \\
\text { basis }\end{array}$ & 5 & 29.41 & 12 & 70.59 & 1.29 & $\mathbf{L}$ \\
\hline \multicolumn{8}{|c|}{ 22. Advise parents to care of the child's diet through } \\
\hline $22-1$ & $\begin{array}{l}\text { Give easy digestion of food and non-abrasive to the mucous } \\
\text { membranes }\end{array}$ & 14 & 82.35 & 3 & 17.65 & 1.82 & $\mathbf{H}$ \\
\hline $22-2$ & Chew food slowly $\quad \checkmark$ & 8 & 47.1 & 9 & 52.9 & 1.47 & $\mathbf{M}$ \\
\hline $22-3$ & $\begin{array}{l}\text { Stay away from eating solid-fiber food (carrots, cucumbers, } \\
\text { apples, cherries }\end{array}$ & 3 & 17.65 & 14 & 82.35 & 1.18 & $\mathbf{L}$ \\
\hline \multicolumn{8}{|c|}{ 23. Teach parents about the cases that reduce bleeding } \\
\hline $23-1$ & Avoid hitting the child on the head $\checkmark$ & 11 & 64.7 & 6 & 35.3 & 1.65 & $\mathbf{M}$ \\
\hline $23-2$ & $\begin{array}{l}\text { Consult a doctor and took treatment before any surgery or } \\
\text { circumcision }\end{array}$ & 6 & 35.29 & 11 & 64.71 & 1.35 & $\mathbf{M}$ \\
\hline $23-3$ & $\begin{array}{l}\text { Baby Monitor continuously during everyday effectiveness } \\
\checkmark\end{array}$ & 8 & 47.1 & 9 & 52.9 & 1.47 & $\mathbf{M}$ \\
\hline \multicolumn{8}{|c|}{ 24.Teaching parents and child protection from accidents } \\
\hline $24-1$ & Choose toys made of plastics $\quad \checkmark$ & 12 & 70.58 & 5 & 29.45 & 1.7 & $\mathbf{H}$ \\
\hline $24-2$ & Floor \& stairs carpeted House Brushes(Carpet) $\checkmark$ & 10 & 58.8 & 7 & 58.8 & 1.59 & $\mathbf{M}$ \\
\hline $24-3$ & $\begin{array}{l}\text { Develop and rubber pad and connect them to the knee and } \\
\text { other joints when starting to walk } \checkmark\end{array}$ & 4 & 23.5 & 13 & 76.5 & 1.235 & $\mathbf{L}$ \\
\hline \multicolumn{8}{|c|}{ 25. Teaching parents and their children protection from joint deformities through the } \\
\hline $25-1$ & Accident Prevention $\quad \checkmark$ & 7 & 41.2 & 10 & 58.8 & 1.4 & $\mathbf{M}$ \\
\hline
\end{tabular}


Assessment Nurses' Knowledge about Hemophilia for Children attending Heredity Blood Disease

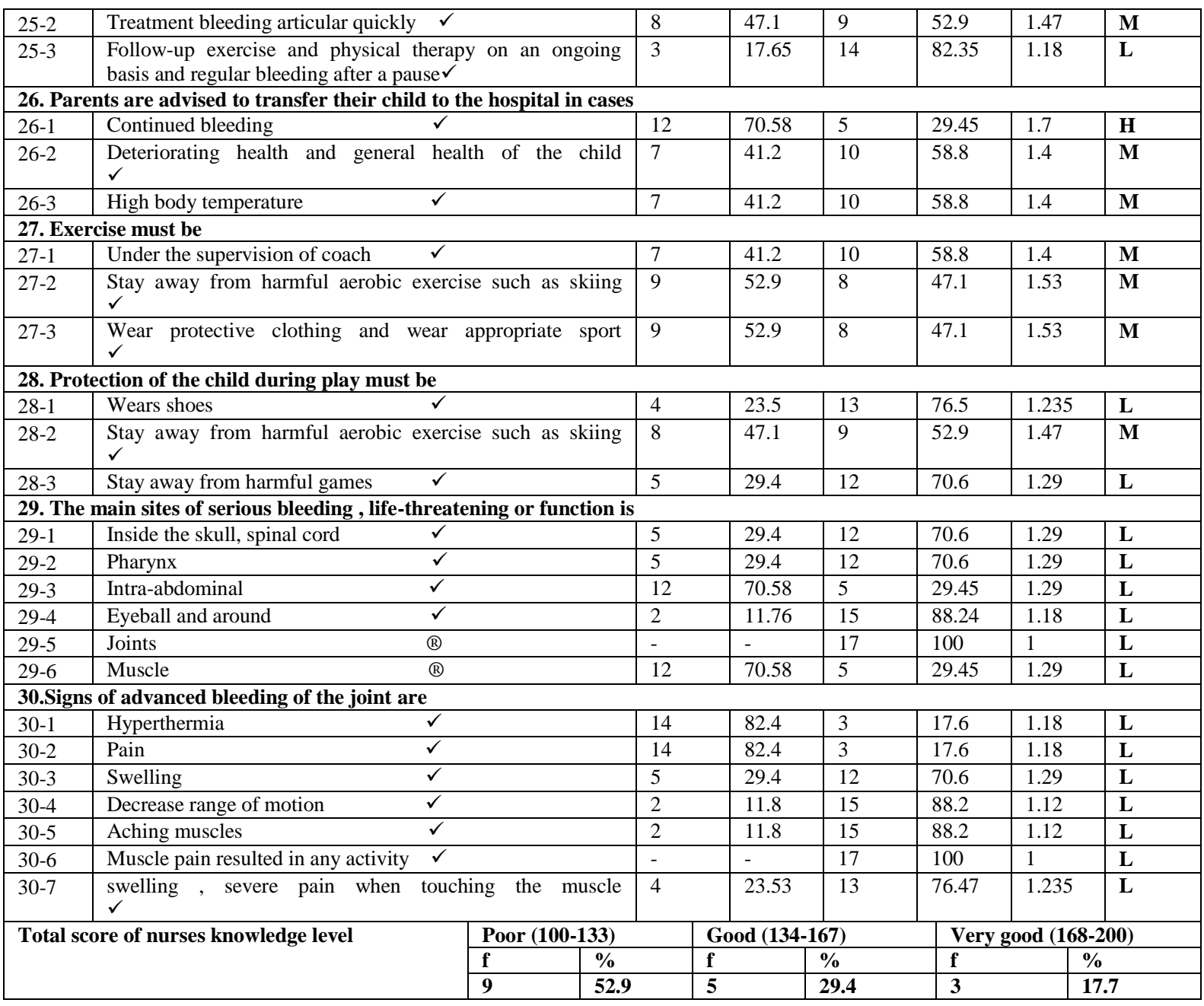

$\mathrm{f}=$ frequency, $\%=$ percentage, $\mathrm{M} . \mathrm{S}=$ mean of score, Ass. $=$ assessment, level of assessment: $(1-1.33)=$ low $=$ $\mathrm{L},(\mathbf{1 . 3 4}-1.67)=$ moderate $=M,(1.68-2.00)=$ high $=H, \checkmark=$ correct answer,$\AA=$ Reverse question

This table shows the nurses respondent to hemophilia knowledge items nurses has moderate level of knowledge when responses to knowledge question (47 items has moderate level of assessment according to the mean of score, 41 items has low level of assessment and 12 items has high level of assessment from total items 100). According to the nurses knowledge total score, this shows (52.9\%) of nurses had poor level of knowledge.

Table (3): Distribution and Association of Nurses' Knowledge with Their Level of Education

\begin{tabular}{|c|c|c|c|c|}
\hline Variables & \multicolumn{4}{|c|}{ Nurses' Knowledge } \\
\hline Level of Education & No. & $\begin{array}{l}\text { Pre-test } \\
\text { Mean } \pm \text { S.D. }\end{array}$ & $\begin{array}{l}\text { Post } 1 \\
\text { Mean } \pm \text { S.D. }\end{array}$ & $\begin{array}{l}\text { Post } 2 \\
\text { Mean } \pm \text { S.D. }\end{array}$ \\
\hline Secondary S Nsg & 6 & $1.142 \pm .032$ & $1.67 \pm 0.083$ & $1.88 \pm 0.047$ \\
\hline nursing Institute & 8 & $1.287 \pm .0717$ & $1.76 \pm 0.104$ & $1.89 \pm 0.038$ \\
\hline Bachelor of Nursing & 3 & $1.63 \pm .0416$ & $1.89 \pm 0.017$ & $1.92 \pm 0.035$ \\
\hline Total & 17 & $1.297 \pm .182$ & $1.75 \pm 0.114$ & $1.89 \pm 0.041$ \\
\hline & & $\begin{array}{l}F=76.79 \\
\text { d.f. }=2 \\
P=0.00\end{array}$ & $\begin{array}{l}F=6.045 \\
\text { d.f. }=2 \\
P=0.013\end{array}$ & $\begin{array}{l}\mathrm{F}=1.088 \\
\text { d.f. }=2 \\
\mathrm{P}=0.364\end{array}$ \\
\hline
\end{tabular}

$\overline{\mathrm{x}} \bar{\mp}$ S.D.=Arithmetic Mean $(\overline{\mathrm{x}})$ and Std. Dev. (S.D.), No. $=$ Number of frequencies, F $=$ Fisher test, d.f. $=$ degree of freedom, $\mathrm{P}=$ probability value.

This table shows that there is statistical significant association between nurses' educational level and their knowledge concerning hemophilic child at ( pre test and post test 2 )of educational program follow up $p$ value < 0.05) when analyzed by ANOVA. there is No statistical significant association between nurses' (other demographic data) and their knowledge concerning hemophilic child at pre test 


\section{Discussion Of The Results}

Knowledge is to constant change adequate knowledge and practice has been recognized as a necessary ingredient in the nurses' ability to lead normal and productive life to their patients ( $\mathrm{Al}-\mathrm{Botany}, 2006)$. She found out that nurse's knowledge and practice in the patients care is considered one of the essential tools in raising the standard of patient care giving by nurse. The nurses must have sound understanding of scientific principles underlying each step of any procedure in order to prevent possible risk factor, so they become able to apply their knowledge into effective care (Al-Barody,2000).

The nurses shows that $(42 \%)$ of them are in age (30 and more) years old, more than the half of the study sample $(64.7 \%)$ are females and this are supported by study done by (Al-sa'idi, 2006) which have a study on pediatric nurses and in his result he mentioned that more than the half of the sample are females, around (47.1\%) of them are graduated from nursing institute while just (17.6\%) are graduated from nursing college, Around $(41.2 \%)$ of them have more than 10 years experiences of job as a nurse, while (23.5\%) of them have less than ( 2 ) years experience in blood diseases wards and this is have agreement with the result of (Alsa'idi, 2006) study in which he indicated that (43.3\%) of the nurses have (1-5) years of experiences in pediatric units this come with the result of study carried by (Najeeb \& Al- Daragy,2004)in the heredity blood disease center. The analysis was conducted on (30) items to assess the nurses knowledge toward hemophilia regarding to definition, general information, sign and symptoms, types and treatment. Concerning the nurses knowledge the study indicated that the nurses have high rates of acceptable level in knowledge related to definition, type of hemophilia and the hereditary role in the transmission of hemophilia (41 items has low level of assessment, the nurses respondent to hemophilia knowledge items nurses has moderate level of knowledge when responses to knowledge question (47 items has moderate level of assessment according to the mean of score, 12 items has high level of assessment from total items 100). According to the nurses knowledge total score, this shows $(52.9 \%)$ of nurses had poor level of knowledge. that mean the nurses who work in the blood diseases ward possess satisfied knowledge which is important for giving care to the patient with hemophilia while regarding the incidence of hemophilia, the treatment of the hemophilia the result indicated that the nurses have acceptable level in knowledge in order to give high quality of patients care, nurses should have high level of knowledge as well as practice While the nurses have a high rate of unacceptable level in the knowledge regarding the type of bleeding of hemophilia $52.9 \%$, place of external bleeding $64.7 \%$, the incidence of hemophilia in the families don't have history of the disease $66 \%$,other names of hemophilia $58.8 \%$ other names of hemophilia $62 \%$, the incidence of hemophilia in male and female $82.2 \%$ And these results have a bad effect on quality of care which provided for the pediatric patient. While the result of the study found that $(64 \%),(46 \%),(54 \%)$ of the sample have uncertain information regarding clotting process, the effect of hemophilia through bleeding on the life style of the carriers and the main complication to replacement therapy is the antibodies. the results shows that there were significant differences between nurses knowledge toward hemophilia regarding educational level, years of experience in nursing and years of experiences in blood disease wards and their age at $\mathrm{P}$ value $\leq 0.05$.also the result shows that there were significant differences between nurses knowledge And their sex and participating in training courses at $P$ value $\leq 0.05$.

As a general nursing school, secondary nursing school, nursing institute and college of nursing have a course for their students concerning hemophilia, but when the investigator saw the score of the samples knowledge after checking their information by the structural instrument, it was found that there were inadequate score in nursing knowledge and this agreed with the recommendations of the first nursing conference which was held in Baghdad 1985 the participant confirmed that the nurses have less knowledge and practice in giving care to their patients. Therefore, there must be more emphasis regarding information in giving care to patients with hemophilia in the study courses of the nursing students, to perform nursing effectively and satisfactory for themselves and for their patients then there must be more emphasis from the hospital policy for the nurses working in blood diseases wards having an educational program.

\section{Conclusion}

The study indicated that the nurses have high rates of acceptable level in knowledge related to definition, type of hemophilia and the hereditary role in the transmission of hemophilia and treatment process of the disease. The finding showed that the nurses have a high rate of unacceptable level in the knowledge regarding the type of bleeding in hemophilia is internal and external, place of internal bleeding, the incidence of hemophilia in the families don't have history of the disease, other names of hemophilia, the samples information about genetic roles for male and females to be incidence hemophilia and the clotting process with the role of factors .The results found that most of the sample has uncertain information regarding, the effect of hemophilia through bleeding on the life style and the main complication to replacement therapy is the antibodies. there is statistical significant association between nurses' educational level and their knowledge concerning hemophilic child 


\section{Recommendations}

Based on the result of the findings of the study, the investigator recommends the following:

1. Special training courses should be designed and constructed for nurses in relation to hemophilia and its complications may be helpful to reinforce their knowledge and practices and promote their experience.

2. Nurse in hematological units must take their opportunity for continuing education to maintain knowledge and practices as well as updating in blood disease nursing.

3. Increasing the number of professional nurses assigned to work in the pediatric and blood disease wards.

4. Providing scientific booklet, publication and journal about hemophilia, is highly recommended.

5. Elevate the scientific level of the nurses regarding the inherited and non inherited blood disorders in the educational program.

\section{References}

[1]. Al-Botany, knowledge and practices of nurses in orthopedic wards concerning cast care ;master thesis, college of nursing ,university of Baghdad 2006

[2]. Al-Barody.N, practice and knowledge of nurses about catheterization in relation to urinary tract infection ,un published thesis in medical-surgical nursing, college of nursing, college of nursing, university of Baghdad 2000 Al-sa'idi, assessment of nurses knowledge toward child with bacterial meningitis at pediatric teaching hospital in Baghdad city ,a master thesis in college of nursing , university of Baghdad 2006.

[3]. Bolton. PH, Pasi KJ. - Hemophilia A and B\|. Lancet. 2003 May 24;361(9371):1801-9.

[4]. Al-sa'idi, assessment of nurses knowledge toward child with bacterial meningitis at pediatric teaching hospital in Baghdad city ,a master thesis in college of nursing ,university of Baghdad 2006.

[5]. Franchini M. - Acquired hemophilia. Hematologyll. 2006 Apr;11(2):119-25

[6]. Giangrande. P, Haemophilia.\|Expert Opin Pharmacotherl. 2005 Aug;6(9):1517-24. Review.

[7]. Graw .J, Brackmann .HH, Oldenburg. J, Schneppenheim .R, Spannagl. M, Schwaab. R,

[8]. -Haemophilia A: from mutation analysis to new therapiesll. 2005 Jun;6(6):488-501.

[9]. Johnson. M, Abshire. TC, Shapiro.AD."Prophylaxis versus episodic treatment to prevent joint

[10]. disease in boys with severe hemophilia". (2007) N. Engl. J. Med. 357 (6): 535-544.

[11]. Najeeb. B, Al Daragye, S; interpersonal relationship between nurses and doctors ,the scientific work of the faculty of the college of nursing ,university of Baghdad ,1984.

[12]. Oldenburg. J, El-Maarri. O, „N New insight into the molecular basis of hemophilia All. Int J Hematol. 2006 Feb;83(2):96-102.

[13]. Polit, D. \&Hungler, B. , nursing principle and methods, 6th edition ,1999, P354, Lippincott, Philadelphia

[14]. Plug. I, Mauser. EP, Bröcker. AH, van. HK, van .JG, van. JE, Willemse. J, Rosendaal. FR.\|l Bleeding in carriers of hemophilia. Bloodll. 2006 Jul 1;108(1):52-6. Epub 2006 Mar 21.

[15]. Roosendaal. G, Lafeber. F, "Prophylactic treatment for prevention of joint disease in hemophilia-cost versus benefit". (2007) N. Engl. J. Med. 357 (6): 603-605.

[16]. Leticia Riley, Mack Womack, Susan Zappa,\| Emergency Room Carell National Hemophilia Foundation 2012 Nursing Working Group - Nurses' Guide to Bleeding Disorders. 